\title{
Right Brain: Withholding treatment from a child with an epileptic encephalomyopathy
}

Aaron Rothstein, MD, and Ariane Lewis, MD

Neurology ${ }^{\circledR}$ 2018;90:857-859. doi:10.1212/WNL.0000000000005416
Correspondence

Dr. Rothstein

aaron.rothstein@nyumc.org

\begin{abstract}
The case of Charlie Gard, an infant who was hospitalized in England due to a mitochondrial DNA depletion syndrome that led to an epileptic encephalomyopathy, was highly publicized. Though Charlie's parents lobbied for him to receive experimental nucleoside replacement therapy as a desperate effort to save him, this request was denied, and after a lengthy legal battle, he died in late July 2017. We discuss the ethical considerations and consequences of this case.
\end{abstract}




\section{Glossary}

GOSH $=$ Great Ormond Street Hospital.

Mitochondrial DNA depletion syndromes are autosomal recessive oxidative phosphorylation disorders characterized by a reduction in mitochondrial DNA leading to severe clinical symptoms. ${ }^{1}$ Charlie Gard, an infant with a mitochondrial DNA depletion syndrome, died from an incurable epileptic encephalomyopathy (a disorder characterized by seizures, altered mental status, and weakness) in a hospital in England in July 2017. His story was highly publicized and imbued with controversy as his family sought to treat him with experimental nucleoside replacement therapy. ${ }^{2}$ Herein, we discuss the ethical considerations and consequences of this case.

\section{Case report}

In August 2016, Charlie was born at Great Ormond Street Hospital (GOSH) in England. When he was 8 weeks old, he became weak and began to lose weight. Testing revealed that he had a mutation in the $R R M 2 B$ gene, which encodes the ribonucleotide reductase $\mathrm{M} 2 \mathrm{~B}$ subunit protein, resulting in the depletion of mitochondrial DNA. He subsequently developed respiratory failure requiring a ventilator, tetraplegia (with only occasional eye opening), and epilepsy. His parents were told that this syndrome would result in death in months. ${ }^{3}$ Charlie's parents found neurologists in both Italy and the United States willing to give him an experimental nucleoside replacement therapy, a treatment that has only been used in patients with myopathy due to a different mitochondrial DNA depletion syndrome. However, because of the severity of Charlie's epileptic encephalomyopathy, GOSH did not allow him to receive the therapy or be transferred. GOSH petitioned the High Court in Britain for permission to take Charlie off the ventilator and focus on comfort measures only. The Court granted this request. Charlie's parents appealed the decision, but multiple British courts denied their appeal. Charlie's case captured the attention of the world, resulting in public comments from the Pope and President Trump and an international petition with 350,000 signatures supporting Charlie's parents' pleas for the right to administer the experimental nucleoside replacement therapy. ${ }^{4}$ In the midst of a protracted 6 months of court proceedings and ethical debate, Charlie deteriorated. In July 2017, his parents acquiesced that the situation was hopeless and that it was too late to help him. He was transferred to hospice, care was withdrawn, and he died. ${ }^{5}$

\section{Discussion}

Should Charlie have been given experimental therapy? From his parents' perspective, this therapy was the only way to prolong their son's life. But did they understand that data for the therapy were limited? Were their expectations realistic or overly optimistic? Were they focused on Charlie's best interests, or were they motivated by grief? From the hospital's perspective, Charlie's disease was very severe, the therapy was unproven, and it may have protracted his suffering. But was it appropriate for them to prevent other physicians from giving him the therapy? In order to determine whether or not Charlie should have been given the experimental therapy, we must consider the basic ethical principles of beneficence, nonmaleficence, and autonomy.

Was there potential for nucleoside replacement therapy to be beneficent (beneficial) to Charlie? Because nucleoside replacement therapy has never been used for RRM2B mitochondrial DNA depletion syndrome, we have no way of knowing if he would have benefited from this therapy. Nevertheless, limited data suggest that it was effective for another mitochondrial DNA depletion syndrome, a TK2 mutation-it led to improved muscle strength and head support in a 3-year-old child and significantly prolonged the lifespan of mice with this disorder. But a TK2 mutation only leads to a myopathy, not an epileptic encephalomyopathy, so would this therapy have helped a patient with a $R R M 2 B$ mutation? ${ }^{6,7}$ Given that it is unclear if this experimental therapy would have been efficacious in this setting, its administration would have been considered compassionate use.

Even if the therapy prolonged Charlie's life, would it have violated the principle of nonmaleficence by causing harm or extending his suffering? Although the therapy has only been used in a limited number of cases of TK2 mutations, it is not known to cause any serious adverse effects. ${ }^{6,7}$ Thus, assessing whether the therapy would cause harm relied largely on a determination of whether or not Charlie was suffering. Notably, attempts to prolong life despite the possibility of causing discomfort are often made for patients with terminal diseases such as metastatic cancer, but these decisions are generally made by patients themselves. Because Charlie was a minor and had no ability to communicate, surrogates, including his parents, the hospital, and the courts, had to make decisions on his behalf. Determining whether he was suffering must have been challenging given that he was tetraplegic, nonverbal, and only occasionally opened his eyes. Surely, parents would not want to prolong their child's suffering, so his parents must not have thought he was uncomfortable. GOSH, however, must have believed otherwise.

If GOSH did not think it was appropriate to give Charlie this therapy, he could have received it if he was transferred to New York or Italy. A decision of whether or not to transfer him should not have been based on the hospital's assessment of 
whether the therapy itself could help or harm him, but rather on Charlie's parents' rights to make autonomous decisions on their child's behalf and whether the transfer itself would be nonmaleficent. This bears similarities to the well-known case of Baby Joseph, a 13-month-old who had another mitochondrial disorder, Leigh disease, and was in a vegetative state in a hospital in Canada. A Canadian court ruled that, despite his family's protestations, the hospital could terminally extubate him. Though they understood that Baby Joseph was terminally ill, his family wanted him to be able to die at home. After obtaining support from an organization called Priests for Life, they brought him to the United States, where a tracheostomy was performed. Baby Joseph died at home 6 months later. ${ }^{8}$ Baby Joseph's case clearly established precedence for international transportation despite physician declaration of futility. Transporting patients on ventilators is fairly common, and if a patient is hemodynamically stable and trained medical staff with necessary equipment is present, this process is relatively benign - even across international borders, as the case of Baby Joseph indicates-so it is unlikely that the risks of transfer would have been greater than the potential benefits. Thus, even if GOSH did not believe it was appropriate to administer the experimental therapy, it does not seem to be just of them to deny Charlie the opportunity to receive the therapy elsewhere, as this violated the ethical principle of patient autonomy.

Charlie Gard's situation was tragic, and it illustrates how challenging it can be to weigh ethical principles, particularly at the end of life. The reality is that Charlie likely would have died with or without experimental nucleoside treatment. However, his parents wanted him to receive this therapy and there were 2 hospitals willing to give it to him. Administering the therapy or transferring Charlie to another hospital willing to give it to him would have been reasonable, practical, and ethically appropriate. While it is unknown whether Charlie was suffering or if the therapy would have been beneficial, the limited available data suggest that it would not have led to serious adverse effects, thereby adhering to the ethical principle of nonmaleficence while striving for beneficence. In addition, allowing Charlie's parents to make medical decisions on his behalf would have demonstrated respect for their autonomy.

Like the case of Baby Joseph, the case of Charlie Gard will have a long-lasting impact and will be referenced in medicoethical conundrums in the future. The consequences of the courts' decisions to deny Charlie the opportunity to be treated with experimental therapy are not restricted to his case. In fact, Charlie's case was cited in another case in July 2017, when a High Court judge in England ruled that care should be withdrawn from another child with brain damage because of the belief that the child was suffering and was going to die soon anyway. ${ }^{9}$ It defies the basic ethical principal of autonomy for physicians and courts to be allowed to unilaterally withdraw care over a patient or family's objections in cases of perceived medical futility in a setting other than brain death, especially when there is a nonmaleficent and possibly beneficent option available. Interestingly, the importance of patient and surrogate autonomy has previously been noted to be valued more in the United States than in England, so if Charlie had been hospitalized in the United States, we suspect he would have been treated with the experimental therapy. ${ }^{10}$

Neurologists, who often deal with severe, incurable debilitating illnesses, should be skilled at considering their ethical obligations in this type of complex case. Goals-of-care discussions and review of treatment options should always include an honest disclosure of potential risks and benefits and a realistic presentation of the expected outcome. In cases of physician-patient/family disagreement, external assistance should be sought from another clinician or an ethics committee.

\section{Author contributions}

Aaron Rothstein was responsible for drafting the manuscript and final approval of the manuscript. Ariane Lewis was responsible for conception, critical revisions, final approval of the manuscript, and supervision.

\section{Acknowledgment}

All details of this case were extracted from the lay press. The authors had no contact with the patient, his family, or his physicians.

\section{Study funding}

No targeted funding reported.

\section{Disclosure}

The authors report no disclosures relevant to the manuscript. Go to Neurology.org/N for full disclosures.

\section{References}

1. Nogueira C, Almeida LS, Nesti C, et al. Syndromes associated with mitochondrial DNA depletion. Ital J Pediatr 2014;40:34.

2. El-Hattab AW, Scaglia F. Mitochondrial DNA depletion syndromes: review and updates of genetic basis, manifestations, and therapeutic options. Neurotherapeutics 2013;10:186-198.

3. The Brief US treatment for Charlie Gard would be futile, Supreme Court rules [Internet]. Times Brief 2017. Available at: thetimesbrief.co.uk/users/39175-the-briefteam/posts/17727-us-treatment-for-charlie-gard-would-be-futile-supreme-courtrules. Accessed November 20, 2017.

4. Clarke H, Veselinovic M. Baby Charlie Gard's new day in court [Internet]. CNN 2017. Available at: cnn.com/2017/07/10/health/charlie-gard-new-hearing/index. html. Accessed November 20, 2017.

5. Wyatt T, Siddique H. Charlie Gard's parents say their "beautiful boy" has died [Internet]. The Guardian 2017. Available at: theguardian.com/uk-news/2017/jul/ 28/charlie-gard-dies. Accessed November 20, 2017.

6. Garone C, Garcia-Diaz B, Emmanuele V, et al. Deoxypyrimidine monophosphate bypass therapy for thymidine kinase 2 deficiency. EMBO Mol Med 2014;6: $1016-1027$

7. Cifuentes S, Francisco S, Alferez I, Molina E. CP-008 Deoxynucleotides DTMP and DCMP in the treatment of mitochondrial myopathy by mutations on the TK2 gene. Eur J Hosp Pharm 2016;23(suppl 1):A4.1-A4.

8. Burkle CM, Benson JJ. End-of-life care decisions: importance of reviewing systems and limitations after 2 recent North American cases. Mayo Clin Proc 2012;87: 1098-1105.

9. Moore C. Brain-damaged baby dies after high court judge allows doctors to withdraw life support against wishes of parents who said "God should decide" in case echoing Charlie Gard's [Internet]. Daily Mail 2017. Available at: dailymail.co.uk/news/article-4731118/ Brain-damaged-baby-dies-case-similar-Charlie-Gard-s.html. Accessed November 20, 2017.

10. Choong KA, Rady MY. Re A (A child) and the United Kingdom code of practice for the diagnosis and confirmation of death: should a secular construct of death override religious values in a pluralistic society? HEC Forum 2018;30:71-89. 


\title{
Neurology
}

\author{
Right Brain: Withholding treatment from a child with an epileptic encephalomyopathy \\ Aaron Rothstein and Ariane Lewis \\ Neurology 2018;90;857-859 \\ DOI 10.1212/WNL.0000000000005416
}

This information is current as of April 30, 2018

Updated Information \&
Services
References
Citations
Subspecialty Collections

Subspecialty Collections

Permissions \& Licensing

Reprints including high resolution figures, can be found at: http://n.neurology.org/content/90/18/857.full

This article cites 6 articles, 1 of which you can access for free at: http://n.neurology.org/content/90/18/857.full\#ref-list-1

This article has been cited by 4 HighWire-hosted articles: http://n.neurology.org/content/90/18/857.full\#\#otherarticles

This article, along with others on similar topics, appears in the following collection(s):

All Ethics in Neurology/Legal issues

http://n.neurology.org/cgi/collection/all_ethics_in_neurology_legal_iss ues

Critical care

http://n.neurology.org/cgi/collection/critical_care

Mitochondrial disorders

http://n.neurology.org/cgi/collection/mitochondrial_disorders

Palliative care

http://n.neurology.org/cgi/collection/palliative_care

Information about reproducing this article in parts (figures,tables) or in its entirety can be found online at:

http://www.neurology.org/about/about_the_journal\#permissions

Information about ordering reprints can be found online:

http://n.neurology.org/subscribers/advertise

Neurology ${ }^{\circledR}$ is the official journal of the American Academy of Neurology. Published continuously since 1951, it is now a weekly with 48 issues per year. Copyright @ 2018 American Academy of Neurology. All rights reserved. Print ISSN: 0028-3878. Online ISSN: 1526-632X.

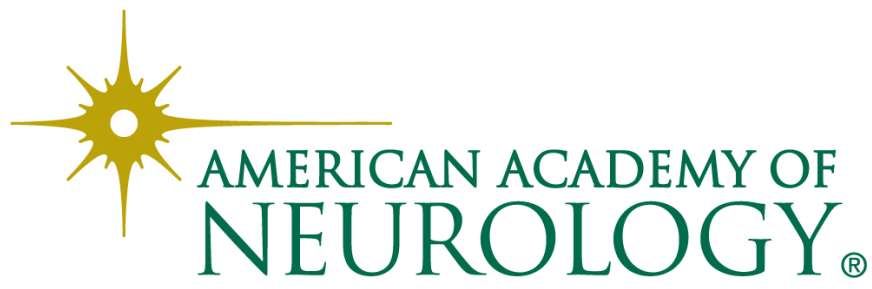

